\title{
Rural profile of oral squamous cell carcinoma (OSCC) survival patients attending in tertiary level hospital in Bogura: a hospital based retrospective observational study.
}

\author{
*Dr. Parometa Barma ${ }^{1}$, Professor Dr. Ibrahim Khalil2 ${ }^{2}$ Professor Dr. Tanzima Yeasmin ${ }^{3}$
}

\section{AFFILIATION:}

1. Dr. Parometa Barma, (BDS, MPH), Indoor medical officer ( OMS), TMSS medical college hospital , Bogura.

2. Professor Dr. Ibrahim Khalil , BDS, MS (Endodontics) Professor and head Department of Conservative Dentistry \& Endodontics City Dental College and general hospital, Dhaka

3. Prof. Dr.Tanzima Yeasmin

Department of Biochemistry and Molecular Biology, University of Rajshahi, Bangladesh

\section{Article info.}

Received: 12 December, 2019

Accepted: 8 February 2020

Volume: 10, Issue-1 April, 2020

DOI: https://doi.org/10.3329/updcj.v10i1.46684

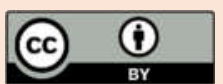

(C) Authors retain copyright and grant the journal right of first publication with the work simultaneously licensed under Creative Commons Attribution License CC - BY 4.0 that allows others to share the work with an acknowledgment of the work's authorship and initial publication in this journal.

https://creativecommons.org/licenses/by/4.0/

Publisher: Update Dental College, Dhaka, Bangladesh

Web: www.updatedentalcollege.edu.bd

E-mail: updci@hotmail.com

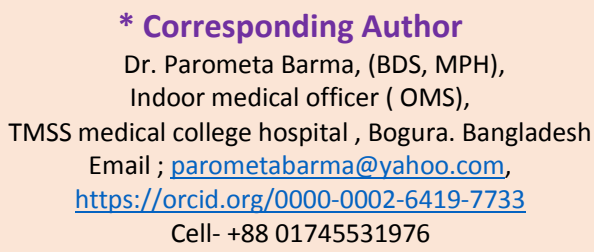

\section{Citation}

Barma P, Khalil I, Yeasmin T. Rural Profile of oral squamous cell carcinoma (OSCC) among patients attending in tertiary level hospital in Bogura: a hospital based retrospective observational study.UpDCJ.2020 Apr;10(1):3-5. Available from: DOI: https://doi.org/10.3329/updcj.v10i1.46684

\begin{abstract}
Developing country like Bangladesh among $90 \%$ of oral malignant neoplasm are arising from squamous layer of oral epithelium which are third leading of this country with severe disfiguration, functiolaesa, psychological impairments and socio-economic hardship. In this study we found the prevalence of OSCC was $6.5 \%$ among total cancer patients in the two tertiary level hospitals of Bogura. Male (70\%) are affected more than in females (30\%). In response to male and female parameter, sex distribution ratio was 2.3:1. The prevalent average age was 55.40 years. About $80 \%$ of ulcer site was buccal mucosa then $10 \%$ were lip mucosa. About $80 \%$ people were habituated by betel nut, leaf with tobacco chewers. Moreover $46.7 \%$ of them were maltreated by quack doctors before. Majority of the patient was in Grade II (56.7\%). Correlation between variable in respect of age and cancer grading was explained. According to these study OSCC patients in north bangle region like Bogura was quite high on ( significant $p$-value $\leq 0.05$ ). Description of oral squamous cell carcinoma on the basis of demographic and clinical profile was the major aim Most of the cases report with intermediate grade of the disease which often leads to decrease the chance of survival of a patient. So new strategies should be considered to overcome the present situation must be undertaken by oral health programs for the early diagnosis and prevention, build up awareness and management and follow up of oral cancer.
\end{abstract}

\section{KEYWORDS: Oral squamous cell carcinoma ( OSCC),}

\section{INTRODUCTION}

Malignant cancer ascending from squamous oral epithelium is one of the most common cancer in developing countries on account of over $90 \%$ of malignant neoplasm of the oral cavity which produce remarkable early visible changes ${ }^{[5]}$. In Bangladesh the number of new cancer patients per year is accounts of 20,0000 (20 lakh) of which oral cancer is about $20 \%$ which is the third leading of this country which is increasing day by day ${ }^{[11]}$.

Basically predominant location of oral squamous cell carcinoma is gender specific parameter because in males the border of the tongue, floor of the mouth/ventral tongue and alveolar mucosa/ gingiva while in females the most frequent site of oral squamous cell carcinoma is the border of the tongue, alveolar mucosa/ gingiva and buccal mucosa/ buccal sulcus. Over all most ubiquitous region of oral squamous cell carcinoma in our oral cavity is border of the tongue (37\%), alveolar mucosa/gingiva (20\%) and floor of the mouth/ ventral surface of the tongue ${ }^{[9]}$.
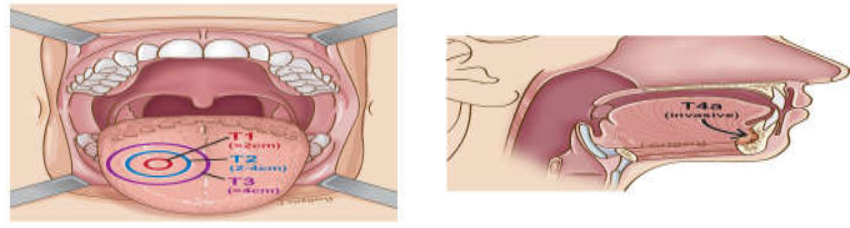

Fig. 1: Diagram showing the staging of oral squamous cell carcinoma ${ }^{[6]}$ 
The learning objective was to assess the epidemiological and clinic pathological sketch of oral squamous cell carcinoma survival patient attending the tertiary level hospital in Bogura including prevalence of oral squamous cell carcinoma, to find out the most striking risk factors of oral squamous cell carcinoma as well as explore the socioeconomic status of an individual which stimulates positive incidence rate of oral cancer $^{[13]}$.
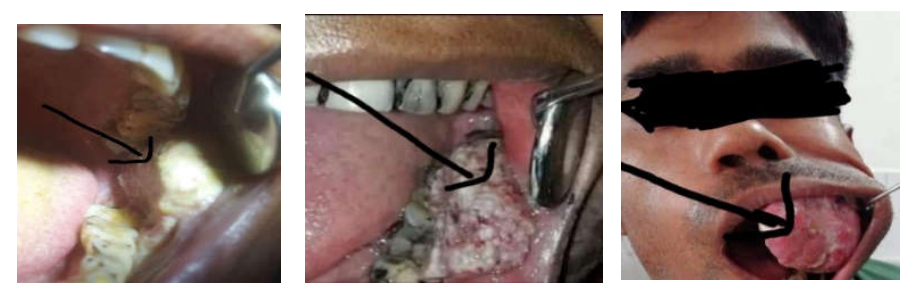

Fig. 2: Oral squamous cell carcinoma on (a) buccal mucosa, (b) alveolar mucosa and (c) palatal mucosa. (From left to right)

\section{METHODOLOGY:}

To implement this objective a retrospective observational study was performed in TMSS Rafatullah Community Hospital and Shaheed Ziaur Rahman Medical College Hospital (ShSMCH) two tertiary level hospital in Bogura with study period six months (May 2019 to October 2019). Inclusion criteria was whom have hispathologically positive case history of oral squamous cell carcinoma ${ }^{[4]}$. At the same time, we excluded patients who are contraindicated for chemotherapy as well as other severe co-morbid diseases. The choice of sampling technique purposive sampling or non-probability to portrait co relational relationship among the parameters. All patients reported in Oral and Maxillofacial Surgery Department and Oncology Department were included as sample of analysis. Data of all histopathologically proven OSCC cases about their both socio demographic and clinical contour was collected through face to face interview by a pretested semi-structured open-ended questionnaire methods ${ }^{[4,5,11]}$. All collected data was analyzed by IBM SPSS version 22 , interpreted by descriptive statistics and to describe correlation between the variable chi-square test and $p$-value was analyzed $^{[4]}$.

\section{RESULTS AND DISCUSSION:}

At that time of study four hundred and sixty five (465) number of cancer patients were admitted in the selected hospitals, who are suffering from various types of cancer, but oral squamous cell carcinoma survival was 30 patient on the basis of their histopathological reports analysis after incisional biopsy. So the percentage of incidence rate of OSCC was analyzed $6.5 \%$ which was quite remarkable. Among them 21 patients were males (70\%) and females 9 (30\%), male female ratio were 2.3:1. Mean age range was $55.40 \pm 10.2$ years. The most remarkable habitual history was betel nut with tobacco chewers (80\%). It was striking $46.7 \%$ participants was maltreated by the quack doctors and $50 \%$ respondents was illiterate (Table 1). So, this socio- demographic profile indicates that besides habitual history and some other co factors like profession are related to cancer progression in our 4 | P a g e society, in that case study shows the farmer are prominent then other profession 33.3\% where $P$ value is highly significant (Table 2). According to the study prevalent oral location of oral squamous cell carcinoma was buccal mucosa, which was $80 \%$ (Chart 2) and among those $56.7 \%$ participants was grade II cancer survival (Chart 1), duration of symptoms development in most cases was $1-12$ months (86.7\%), p value- 0.046 significant value (Table 3 ).

Table 1 Co factors related to carcinoma progression

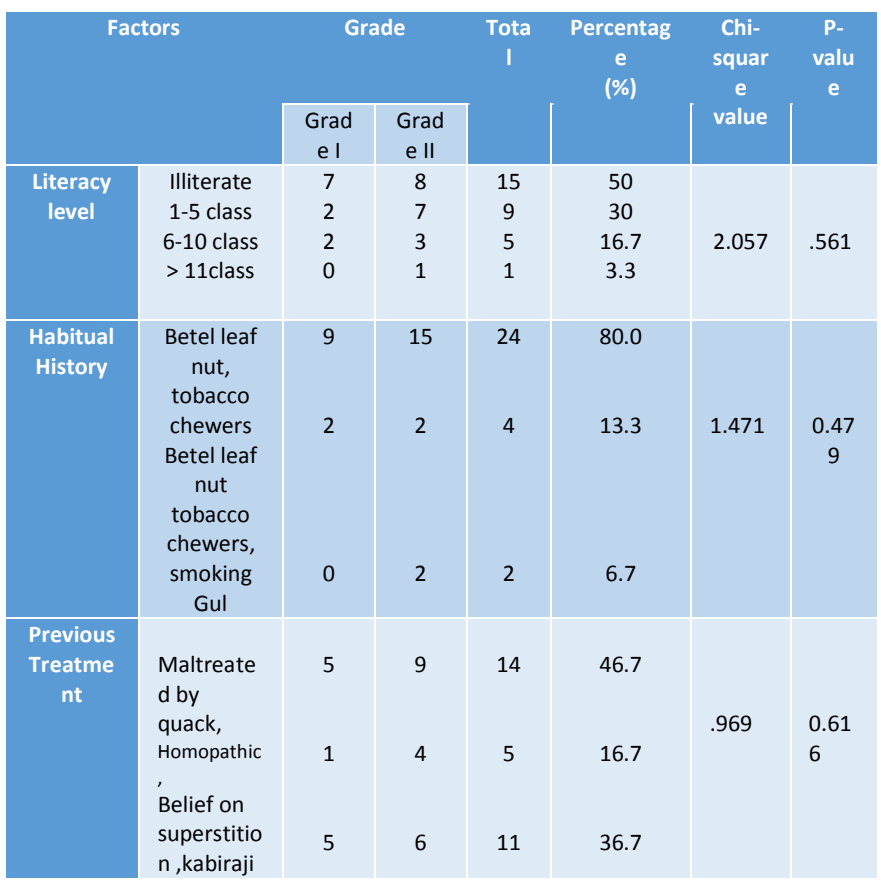

Table 2 Occupational status related to carcinoma progression

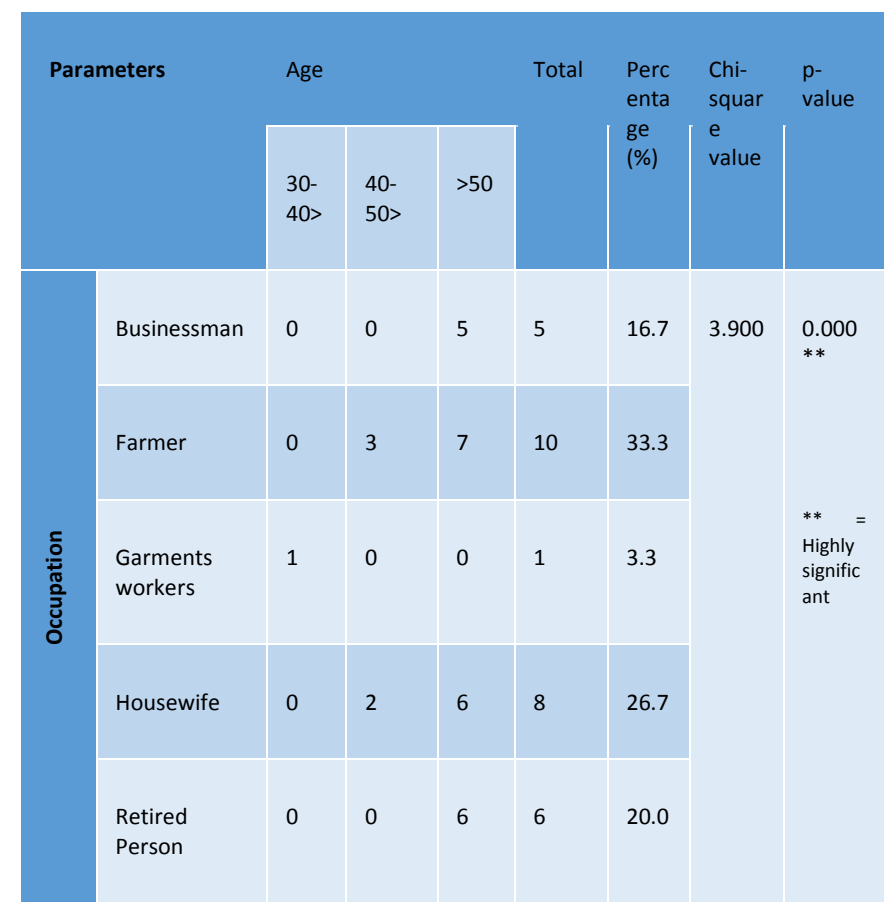

Website: https://www.banglajol.info/index.php/UpDCJ 
Table 3 Duration of symptoms development in cancer patient

\begin{tabular}{|c|c|c|c|c|c|c|c|}
\hline & \multirow[t]{2}{*}{ Factors } & \multicolumn{2}{|c|}{ Grade } & \multirow{2}{*}{$\begin{array}{c}\text { Tot } \\
\text { al }\end{array}$} & \multirow{2}{*}{$\begin{array}{c}\text { Percent } \\
\text { age } \\
(\%)\end{array}$} & \multirow{2}{*}{$\begin{array}{c}\text { Chi- } \\
\text { square } \\
\text { value }\end{array}$} & \multirow{2}{*}{$\begin{array}{c}\text { P- } \\
\text { value }\end{array}$} \\
\hline & & $\begin{array}{c}\text { Grad } \\
\text { el }\end{array}$ & $\begin{array}{c}\text { Grade } \\
\text { II }\end{array}$ & & & & \\
\hline \multirow{3}{*}{$\begin{array}{c}\text { Durati } \\
\text { on of } \\
\text { sympt } \\
\text { oms }\end{array}$} & $1-12$ months & 8 & 18 & 26 & 86.7 & \multirow{3}{*}{6.150} & \multirow{3}{*}{$.046^{*}$} \\
\hline & 12-4months & 3 & 0 & 3 & 10.0 & & \\
\hline & 24-36months & 0 & 1 & 1 & 3.3 & & \\
\hline
\end{tabular}

* = significant value

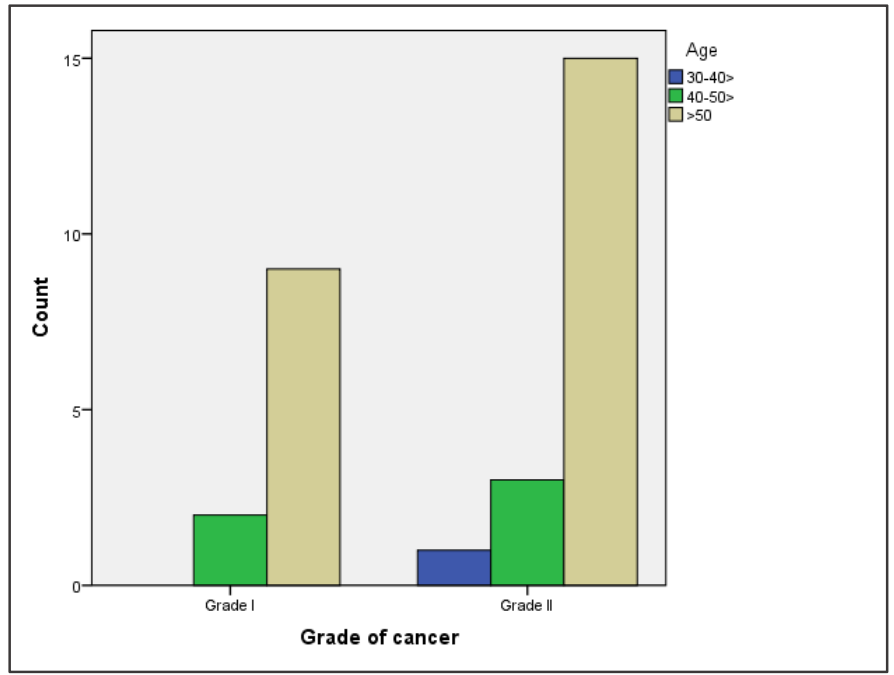

Chart 1 Histopathological grade of OSCC in study age group

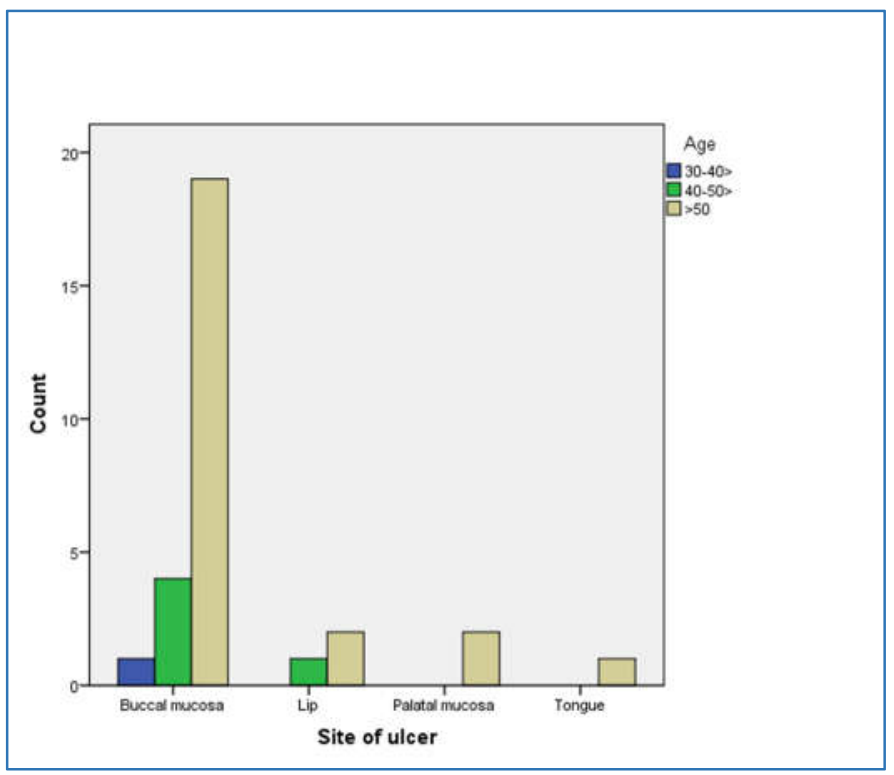

Chart 2 Prevalent site of OSCC in study age group

\section{REFERENCES:}

1. Barma P. (2019). Profile of oral squamous cell carcinoma among patients attending tertiary level hospital in Bogura; A hospital based study. MPH thesis paper of IBSc in Rajshahi University.

2. Cawson RA. (1969) . Leukoplakia and oral cancer. Proc R soc Med. 62: 610-4.

https://doi.org/10.1177/003591576906200637

3. Common Cancers in Bangladesh.(2018).Annual statistical report of Cancer awareness foundation of Bangladesh.

4. Hannan, M. A., Rahman, M. A., Hossain, S., \& Rahman, Q. (2018). Role Of Habitual Risk Factors On Oral Squamous Cell Carcinoma. Update Dental College Journal, 8(1), 29-35.

https://doi.org/10.3329/updcj.v8i1.38409

5. Hossain, M. A., Ahmed, M. M., Rahman, A. S., Haider, M. N., \& Alam, A. S. (2018). Epidemiological study of oral squamous cell carcinoma: $A$ hospital based study in Dhaka city. TAJ: Journal of Teachers Association, 28(2), 22-25.

https://doi.org/10.3329/taj.v28i2.39075

6. https://headandneckcancerguide.org/adults/introduction-to-head-andneck-cancer/oral-cancers/tongue-cancer/stage-cancer/.

7. Markopoulos, A. K. (2012). Current Aspects on Oral Squamous Cell Carcinoma. The Open Dentistry Journal, 6(1), 126-130. https://doi.org/10.2174/1874210601206010126

PMid:22930665 PMCid:PMC3428647

8. Norman Wood and Paul Goaz, (2011). Differential Diagnosis of Oral and Maxillofacial Lesions ,5th Edition.

9. Pires, F. R., Ramos, A. B., Oliveira, J. B. C. de, Tavares, A. S., Luz, P. S. R. da, \& Santos, T. C. R. B. dos. (2013). Oral squamous cell carcinoma: clinicopathological features from 346 cases from a single Oral Pathology service during an 8-year period. Journal of Applied Oral Science, 21(5), 460-467.

https://doi.org/10.1590/1679-775720130317

PMid:24212993 PMCid:PMC3881836

10. Rahman, Q. (2016). Oral cancer: One of the leading malignancies in Bangladesh. Bangabandhu Sheikh Mujib Medical University Journal, 7(2), 75-76.

https://doi.org/10.3329/bsmmuj.v9i1.28954

https://doi.org/10.3329/bsmmuj.v7i2.29293

11. Rahman, S., Sarker, M., Khan, M. H., Biswas, S., \& Saha, M. (2015). Clinical profile of oral squamous cell carcinoma patients attending a tertiary care hospital. Bangladesh Medical Journal Khulna, 47(1-2), 3-6. https://doi.org/10.3329/bmik.v47i1-2.22554

12. Sadat, S. M. A. (2013). Oral squamous cell carcinoma of bangladeshi patients: a survival study. International Journal of Oral and Maxillofacial Surgery, 42(10), 1281. https://doi.org/10.1016/j.ijom.2013.07.366

13. Singh, M. P., Kumar, V., Agarwal, A., Kumar, R., Bhatt, M. L. B., \& Misra, S. (2016). Clinico-epidemiological study of oral squamous cell carcinoma: A tertiary care centre study in North India. Journal of Oral Biology and Craniofacial Research, 6(1), 32-35. https://doi.org/10.1016/i.jobcr.2015.11.002 PMid:26937366 PMCid:PMC4756063 